Egyptian Poultry Science Journal

http://www.epsj.journals.ekb.eg/

ISSN: 1110-5623 (Print) - 2090-0570 (Online)

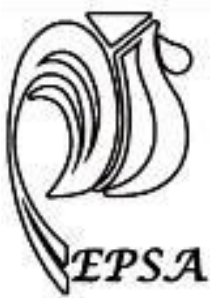

\title{
EFFICACY OF DIETARY ZINC OXIDE NANOPARTICLES SUPPLEMENTATION ON SERUM BIOCHEMICAL, NUTRIENTS RETENTION AND CHEMICAL COMPOSITION OF MEAT AND TIBIA IN BROILER CHICKENS \\ Faten A. M. Attia *1, Haiam S. Abd EL-Haliem¹, H. S. Saber ${ }^{1}$ I. H. Hermes ${ }^{1}$ and K. Y. Farroh ${ }^{2}$ \\ ${ }^{1}$ Anim. Prod. Dep., Fac. of Agric., Suez Canal Uni., Ismailia, Egypt, PO Box 41522. \\ ${ }^{2}$ Nanotechn. and Advanced Mater. Central Lab, Agric.l Rese. Center, Giza, Egypt.
}

*Corresponding author: Faten A. M. Attia Email: famattia@yahoo.com

Received: 24/11/2019 Accepted: 05/01/2019

ABSTRACT: A total of 192 unsexed day-old "Cobb" broiler chicks were used to evaluate the effects of different levels of dietary nano zinc oxide $(\mathrm{N}-\mathrm{ZnO})$ on nitrogen and minerals retention, blood serum measurements, meat chemical composition and tibia minerals of broiler chickens. Chicks were randomly distributed into six treatments of four replicates eight chicks each. A control contained $100 \mathrm{mg}$ inorganic $\mathrm{ZnO} / \mathrm{kg}$ diet (I-ZnO) and 100, 80, 60, 40 and $20 \mathrm{mg} \mathrm{N}-\mathrm{ZnO} / \mathrm{kg}$ diet were fed. Diets supplemented with different levels of N$\mathrm{ZnO}$ had significant effect on blood serum parameters except for total protein and cholesterol. The highest contents of (albumin, high density lipoprotein, low-density lipoprotein, lactate dehydrogenase, superoxide dismutase, calcium, phosphorous and zinc) and the lowest (triglycerides, creatinine, uric acid, aspartate transferase, alanine transferase, alkaline phosphatase and malondialdehyde) were obtained with $20 \mathrm{mg} \mathrm{N}-\mathrm{ZnO} / \mathrm{kg}$ diet. A significant reduction in moisture and fat and significant increase in crude protein, ash and minerals $(\mathrm{Ca}, \mathrm{P}$ and $\mathrm{Zn}$ ) of breast and thigh meats were observed with $\mathrm{N}-\mathrm{ZnO}$ treatments; the lowest and the highest percentages, respectively, of the former criteria were recorded with $20 \mathrm{mg} \mathrm{N}-\mathrm{ZnO}$. Birds fed N-ZnO (40 and 20), (60, 40 and 20) and $20 \mathrm{mg} / \mathrm{kg}$ diet had the highest significant tibia $\mathrm{Ca}, \mathrm{Zn}$ and $\mathrm{P}$ percentages, respectively. Nano-ZnO treatments significantly increased the retention percentages except for $\mathrm{Zn}$. Birds fed $40 \mathrm{mg} \mathrm{N}-\mathrm{ZnO} / \mathrm{kg}$ diet exhibited the highest nitrogen, $\mathrm{Ca}, \mathrm{P}$ and $\mathrm{Zn}$ retention. It could be concluded that supplementation of $\mathrm{N}-\mathrm{ZnO}$ to broiler diet improved birds' physiological status, meat carcass quality, bone mineralization and nutrients retention. The lower levels of $\mathrm{N}-\mathrm{ZnO}$ (20 and 40 $\mathrm{mg} / \mathrm{kg}$ diet) revealed promising results with no harmful effect on birds' health status.

Key words: broiler, zinc oxide nano particle, nutrients retention, meat quality, serum parameters. 
Faten A. M. Attia et al.

\section{INTRODUCTION}

Zinc (Zn) as a vital trace mineral plays three important roles in the body to facilitate the biological functions: as a catalyst, regulator and structural constituent (Stefanidou et al., 2006). It is a cofactor of over 300 enzymes (metalloenzymes) from all six enzyme classes. Thus it has been known to be essential for immune function, wound healing, growth, metabolism, fertility, and oxygen-free radical scavenging in animals (Kietzmann and Braun, 2006; Chand et al., 2014 and Vinus and Sheoran, 2017). Although, the recommended level of $\mathrm{Zn}$ in broiler diet is $40 \mathrm{mg} / \mathrm{kg}$ diet (NRC, 1994); the optimal level was estimated to be 80.50 to 84.09 $\mathrm{mg} / \mathrm{kg}$ of diet (Huang et al., 2007). However, Štenclová et al. (2016) reported that supplementation of 120,40 or $20 \mathrm{mg}$ $\mathrm{Zn}$ oxide $(\mathrm{ZnO})$ to corn-wheat-soybean meal basal diet, containing $25.84 \mathrm{mg}$ $\mathrm{Zn} / \mathrm{kg}$, had no significant effect on the growth performance of broiler chickens. Moreover, diets supplemented with high levels of $\mathrm{Zn}$ may increase $\mathrm{Zn}$ excretion in the excreta resulting in environmental pollution, influence the other trace elements balance and decrease vitamins and nutrients stability. Also, the longterm implementation might increase $\mathrm{Zn}$ residual in the body (Case and Carlson, 2002; Broom et al., 2003 and Sundaresan et al., 2008)

The bio-available $\mathrm{Zn}$ to poultry vary depending on the form added to diets; it is higher in organic form compared with inorganic but organic $\mathrm{Zn}$ application in poultry feed is limited due to its higher cost (Zhao et al., 2014). Nanoparticles as feed additives have been recently used in animal feed. Elements processed in nanoparticles gain unique physical characteristics such as a large surface area with high activity, many surface-active centers and, high catalytic efficiency which resulted in better absorption and utilization (Rai and Ingle, 2012). Nano trace elements enter the animal body through direct cell membrane penetration; therefore, its utilization rate is higher than the ordinary inorganic trace elements. It was found that the utilization coefficient of the inorganic trace elements about $30 \%$ while it was close to $100 \%$ with nano trace elements. Consequently, positive effects were resulted such as improving appetite, increasing daily gain, decreasing feed to gain ratio, improving immunity and diminish use of antibiotics thus increasing food safety for the consumer. Also, it can reduce the odor of poultry manure, which is conducive to bring environment improvement (Huang et al., 2015). In addition, some improvements were detected in meat chemical composition, muscle $\mathrm{Zn}$ concentration, blood serum parameters, antioxidant defense and cellular immunity in broilers with the supplementation of nano $\mathrm{ZnO}$ particles (Esfahani et al., 2015; Hafez et al., 2019 and Ramiah et al., 2019).

The lack of information with a satisfactory degree on usage nanotechnology in poultry nutrition needs more investigation. Therefore, the aim of the current study was to investigate the effect of dietary $\mathrm{ZnO}$ nanoparticles $(\mathrm{N}-\mathrm{ZnO})$ on nitrogen and minerals retention, blood serum measurements, meat chemical composition and tibia minerals of broiler chickens. 
broiler, zinc oxide nano particle, nutrients retention, meat quality, serum parameters

\section{MATERIALS and METHODS Birds and management:}

An experiment was carried out at the Poultry Research Farm, Department of Animal Production, Faculty of Agriculture, Suez Canal University, Ismailia, Egypt. One hundred and ninety-two, one-day-old unsexed, "Cobb" broiler chicks obtained from a commercial hatchery were used. Chicks were individually weighed, wingbanded and randomly distributed into 24 groups (similar in average body weight) of eight chicks each. Chicks were raised in brooder batteries with wire mesh floors. Feed and water were provided ad-libitum during the 6 weeks experimental period. Artificial light was provided for 23 hours per day and the ambiance temperature was $34-35^{\circ} \mathrm{C}$ during the first week of age and gradually decreased $2-3^{\circ} \mathrm{C}$ per week till the third week of age. Electric fans were used to provide ventilation. All chicks were kept under the same management, hygienic and environmental conditions.

\section{Treatments and the experimental diets:}

A completely randomized design of six treatments of four replicate each was used to evaluate the effects of different levels of dietary $\mathrm{N}-\mathrm{ZnO}$ particles on nitrogen and minerals retention, blood serum measurements, meat chemical composition and tibia minerals. The first treatment (control) contained $100 \mathrm{mg}$ inorganic $\mathrm{ZnO} / \mathrm{kg}$ diet (I-ZnO, as recommended by the manual of Cobb, 2015). Diets were supplemented with 100, 80, 60, 40 and 20 $\mathrm{mg} \mathrm{N}-\mathrm{ZnO} / \mathrm{kg}$ diet to form treatments two to six, respectively. Chicks were fed three types of diets in mash form and were formulated to be iso-caloric and isonitrogenous. Diets were starter (0 to 3 weeks of age), grower (4 to 5 weeks of age) and finisher $\left(6^{\text {th }}\right.$ week of age $)$. The experimental diets composition and chemical analysis (A.O.A.C, 1990) are shown in Table 1.

Synthesis of nano zinc oxide particles: Zinc oxide nanoparticles were prepared by the precipitation method (Kumar et al., 2013). Sodium hydroxide solution (122.40 $\mathrm{g}$ dissolved in $1500 \mathrm{ml}$ of deionized water) was added drop wise under magnetic stirring to zinc sulfate heptahydrate solution $(431.31 \mathrm{~g}$ dissolved in $1500 \mathrm{ml}$ of deionized water) and the stirring was continued for $12 \mathrm{hr}$ after the completed addition. The precipitates were filtered, washed by pure water several times, dried at $100{ }^{\circ} \mathrm{C}$ for $30 \mathrm{~min}$ and calcined at $500^{\circ} \mathrm{C}$ for $2 \mathrm{hr}$. The crystalline and phase structure of the synthesized $\mathrm{ZnO}$ was studied by an $\mathrm{X}$-ray diffract meter (XRD, $\mathrm{X}^{\prime}$ Pert PRO). The morphology and size were determined by the transmission electron microscopy (TEM, JEOL JEM-2100). All chemicals used were used without further purification (Research-Lab Fine Chem IndustriesMumbai 400-002, India). All the preparation and characterization processes were conducted at Nanotechnology and Advanced Materials Central Lab, Agricultural Research Center, Egypt.

\section{Nutrients balance trial:}

At five weeks of age, digestion trial was performed. The total apparent retention of nitrogen $(\mathrm{N})$, Calcium $(\mathrm{Ca})$, phosphorus $(\mathrm{P})$ and $\mathrm{Zn}$ was determined using one bird per replicate (four birds per treatment). The finisher diet was fed. The trial was extended for six days, three days of adaptation followed by three days of feces collection. Birds were housed in individual 
Faten A. M. Attia et al.

digestion cages. Feed intake and excreta voided were accurately determined. The excreta from each bird was separately collected, cleaned from feathers, weighed and dried in a forced oven at $70^{\circ} \mathrm{C}$ for 24 hr. The dried excreta were weighed, grind and placed in glass jars until chemical analyses. Calcium, $\mathrm{P}$ and $\mathrm{Zn}$ in the experimental diets and excreta were determined according to Fodor et al. (1973), while nitrogen was determined according to the A.O.A.C (1990).

\section{Blood serum parameters:}

Close to the average body weight, two birds were chosen from each replicate at the end of the experimental period (6 weeks of age). Birds were fasted overnight with free access to water. Selected birds were individually weighed and slaughtered. During bleeding, blood samples were collected from each bird in a tube. Serum was separated by centrifugation and stored at $-20^{\circ} \mathrm{C}$ until analysis. Serum constituent measurements of total protein, albumin, triglyceride, cholesterol, high density lipoprotein (HDL), low-density lipoprotein (LDL), creatinine, uric acid, $\mathrm{Ca}, \mathrm{P}, \mathrm{Zn}$, superoxide dismutase (SOD), alkaline phosphatase (ALP), aspartate transferase (AST), alanine transferase (ALT), lactate dehydrogenase (LDH) and malondialdehyde (MDA) were colorimetrically determined using commercial kits (Egyptian Company for Biotechnology, S.A.E, and Diamond, D-P, International) as described by Young and Friedman (2001).

Chemical analysis of meat:

The eviscerated carcass from each bird was deboned; meat of the breast and thigh was minced and dried. The chemical composition of the dry meat samples were done according to A.O.A.C. (1990). The dry matter was evaluated by drying in an oven at $135^{\circ} \mathrm{C}$ and moisture percentage was calculated. The crude protein (CP) was determined by Kjeldahl method and crude fat by Soxhlet method using petroleum ether. The crude ash was determined by ashing meat sample in a muffle furnace oven at a temperature of $550^{\circ} \mathrm{C}$ for $2 \mathrm{hr}$. Nitrogen-free extract (NFE) was calculated by the difference. Calcium, $\mathrm{P}$ and $\mathrm{Zn}$ were evaluated using the atomic absorption spectrometry (Fodor et al., 1973).

\section{Tibia minerals:}

The right tibia of each carcass was cleaned of adhering tissues, including cartilage caps, and washed with distilled water. Tibia bones were dried in a hot air oven at $105^{\circ} \mathrm{C}$ for 24 hours. The dried tibias were ashed at $600^{\circ} \mathrm{C}$ for 24 hours in a muffle furnace and the ash was weighed. Percentages of $\mathrm{Ca}$ and $\mathrm{P}$ and $\mathrm{Zn}(\mathrm{ppm})$ were determined in the ash (Fodor et al., 1973).

\section{Statistical analysis:}

Data were subjected to analysis for significance by a one-way ANOVA model (as a completely randomized design) using the General Linear Models (GLM) procedures of SPSS (IBM SPSS statistics, version 22, USA). Treatments differences were considered significant at $\mathrm{P} \leq 0.05$ and $\mathrm{P} \leq 0.01$ for all measurements. Means comparisons were performed using Duncan's multiple range tests (Duncan, 1955).

\section{RESULTS AND DISCUSSION 1. Nano zinc oxide particles \\ The size of $\mathrm{N}-\mathrm{ZnO}$ powder was investigated by the XRD and TEM analyses and has shown clear results.}


broiler, zinc oxide nano particle, nutrients retention, meat quality, serum parameters

\begin{abstract}
1.1. XRD analysis results:
The XRD pattern of the synthesized $\mathrm{ZnO}$ nano-particles is shown in figure (1). The peaks at $2 \theta=31.77^{\circ}, 34.4^{\circ}, 36.26^{\circ}, 47.54^{\circ}$, $56.60^{\circ}, 62.86^{\circ}, 66.38^{\circ}, 67.95^{\circ}, 69.09^{\circ}$, $72.57^{\circ}$, and $76.97^{\circ}$ were assigned to (100), (002), (101), (102), (110), (103), (200), (112), (201), (004), and (202) of $\mathrm{ZnO}$ nanoparticles, indicating that the crystalline structure of synthesized $\mathrm{ZnO}$ nano-particles presented a hexagonal phase structure of the wurtzite (Zincite, JCPDS 5-0664).
\end{abstract}

\subsection{Transmission Electron Microscopic analysis results:}

High Resolution Transmission Electron Microscopic (HR-TEM) studies were carried out to find out the exact particle size of synthesized $\mathrm{ZnO}$. Transmission Electron Microscopic images as illustrated in Figure (2), $\mathrm{ZnO}$ nano-particles which having particle size in the range of 19-39 $\mathrm{nm}$ with nearly spherical shaped particles.

\section{Blood serum parameters:}

\subsection{Serum constituents:}

Diets supplemented with $\mathrm{N}-\mathrm{ZnO}$ increased serum total protein compared with the control with no significant difference (Table 2). This increase might be attributed to the role of $\mathrm{Zn}$ in protein synthesis (Ibs and Rink, 2003). An increase $(P \leq 0.01)$ in serum albumin and a reduction $(\mathrm{P} \leq 0.01)$ in creatinine and uric acid were observed with the supplementation of $\mathrm{N}-\mathrm{ZnO}$ particles; the highest and the lowest values, respectively, of the former serum parameters were obtained with level of 20 $\mathrm{mg} \mathrm{N}-\mathrm{ZnO} / \mathrm{kg}$ diet and the vice versa for the control.

These results were partially consistent with Hassan et al. (2017) who showed that serum total protein was increased with the supplementation of 60 and $30 \mathrm{mg} \mathrm{N}-$ $\mathrm{ZnO} / \mathrm{kg}$ of rabbit diets in comparison with $\mathrm{Zn}$-free premix diet or supplemented with $60 \mathrm{mg} \mathrm{I}-\mathrm{ZnO} / \mathrm{kg}$ of diet. However, the present data divergent with those of ElKatcha et al. (2017) who observed that the replacement of $\mathrm{I}-\mathrm{ZnO}$ by $\mathrm{N}-\mathrm{Zn}$ in broiler diets had no significant effect on blood serum total protein, albumin and uric acid concentrations.

A significant reduction in triglycerides and a significant increase in HDL and LDL contents were recorded with $\mathrm{N}-\mathrm{ZnO}$ levels (Table 2). The lowest $(\mathrm{P} \leq 0.01)$ triglycerides and the highest $(\mathrm{P} \leq 0.01) \mathrm{HDL}$ values were observed with 40 and $20 \mathrm{mg}$ $\mathrm{N}-\mathrm{ZnO}$ diets while 60, 40 and $20 \mathrm{mg} \mathrm{N}$ $\mathrm{ZnO}$ diets recorded the highest $(\mathrm{P} \leq 0.05)$ LDL values in comparison with the control. Likewise, the lowest cholesterol content was observed with $20 \mathrm{mg} \mathrm{N}-\mathrm{ZnO}$ diet compared with the control but no significant difference.

In similar direction, the replacement of I$\mathrm{Zn}$ with different levels of $\mathrm{N}-\mathrm{Zn}$ particles reduced $(\mathrm{P} \geq 0.05)$ blood serum triglycerides while increased total cholesterol and HDL. However, no effect on serum LDL and very low density lipoprotein (VLDL) concentrations of broilers was found (ElKatcha et al., 2017). In addition, N-Zn decreased $(\mathrm{P} \leq 0.05)$ serum total cholesterol, VLDL and triglyceride, in broiler chicks with the lowest values were observed with $\mathrm{N}-\mathrm{Zn}$ diets. In spite of that, N-Zn supplementation had no effect on serum lipid and HDL (Ibrahim et al., 2017). Similar results have been obtained by Ahmadi et al.(2013) who reported that supplementation of 60 or $90 \mathrm{mg} \mathrm{N}-\mathrm{ZnO} / \mathrm{kg}$ of broiler diet decreased serum 
Faten A. M. Attia et al.

triglycerides, total cholesterol and LDLcholesterol with no significant differences, however, HDL-cholesterol increased (P $<0.05)$ in comparison with the control diet (zero $\mathrm{N}-\mathrm{ZnO}$ ). Besides, the highest serum HDL was observed with $90 \mathrm{mg} \mathrm{N}-\mathrm{ZnO} / \mathrm{kg}$ of diet while $120 \mathrm{mg} \mathrm{N}-\mathrm{ZnO}$ recorded the highest LDL. Although, serum total cholesterol and HDL were significantly increased at $20 \mathrm{mg} \mathrm{N}-\mathrm{ZnO} / \mathrm{kg}$; no significant effect was detected by $\mathrm{N}-\mathrm{ZnO}$ $(10,20$ and $40 \mathrm{mg})$ on serum triglyceride of broiler chickens (Fathi et al., 2016). A change of cholesterol levels in blood plasma may be due to the role of $\mathrm{Zn}$ in enzyme action as $\mathrm{Zn}$ forms an integral part of several enzymes (metalloenzymes) that are severed in lipid digestion and absorption Al-Daraji and Amen (2011).

\section{2. Serum enzymes and minerals:}

Supplementation of different levels of N$\mathrm{ZnO}$ decreased $(\mathrm{P} \leq 0.01)$ liver enzymes (AST and ALT), ALP and MDA contents, the lowest contents were obtained by level of $20 \mathrm{mg} \mathrm{N}-\mathrm{ZnO} / \mathrm{kg}$ diet (Table, 3). Conversely, a significant increase in serum LDH $(\mathrm{P} \leq 0.05)$ and SOD $(\mathrm{P} \leq 0.01)$ enzyme contents were obtained by $\mathrm{N}-\mathrm{ZnO}$ treatments, the lowest values recoded by the control diet in comparison with the other treatments.

These data are in harmony with those obtained by Berg and Shi (1996) and Walsh et al. (1994) who stated inverse relationship between $\mathrm{N}-\mathrm{ZnO}$ and MDA values and serum ALT and AST enzyme concentrations. Besides, Ibrahim et al. (2017) reported that serum MDA level was decreased $(\mathrm{P} \leq 0.05)$, while, the $\mathrm{Cu} / \mathrm{Zn}-\mathrm{SOD}$ level was increased $(\mathrm{P} \leq 0.05)$ with dietary $\mathrm{N}-\mathrm{ZnO}$, which indicated that adding of $\mathrm{N}-$
Zn increased the antioxidant activity in broilers. However, the hepatic activity of AST and ALT were not significantly influenced by different dietary sources of $\mathrm{Zn}$. Also, the activity of serum AST, ALT, ALP and LDH enzymes were significantly decreased with the supplementation of different levels of $\mathrm{N}-\mathrm{ZnO}$ in broiler diets. On the other side, SOD was significantly increased and MDA was decreased at 60 or $90 \mathrm{mg} \mathrm{N}-\mathrm{ZnO} / \mathrm{kg}$ of diet in comparison with the other levels (zero, 30, $120 \mathrm{mg} \mathrm{N}$ $\mathrm{ZnO} / \mathrm{kg}$ ). They concluded that 60 or $90 \mathrm{mg}$ $\mathrm{N}-\mathrm{ZnO} / \mathrm{kg}$ of diet improved serum enzymes activity and antioxidant condition of broiler chicks (Ahmadi et al., 2014).

However, Fathi et al. (2016) demonstrated that serum HDL, ALP and SOD were significantly increased and MDA reduced at $20 \mathrm{mg} \mathrm{N}-\mathrm{ZnO} / \mathrm{kg}$. In addition, $\mathrm{N}-\mathrm{ZnO}$ $(10,20$ and $40 \mathrm{mg})$ had no significant effect on serum AST and ALT of broiler chickens. Moreover, Zhao et al. (2014) affirmed that $20 \mathrm{mg} \mathrm{N}-\mathrm{ZnO} / \mathrm{kg}$ of broiler diet had a similar effect on the action of $\mathrm{Cu}-\mathrm{Zn}-\mathrm{SOD} 1$ in serum and liver tissue as that of the control $(60 \mathrm{mg} \mathrm{ZnO})$. They attributed this due to the role of zinc as a cofactor of antioxidant enzyme (Cu-ZnSOD1) and it is also required to activate these enzymes that scavenge reactive oxygen species, reducing oxidative stress. Data in Table 3 showed that serum $\mathrm{Ca}, \mathrm{P}$ and $\mathrm{Zn}$ were significantly increased $(\mathrm{P} \leq 0.01)$ with the supplementation of $\mathrm{N}$ $\mathrm{ZnO}$ in the diets. Birds fed 40 and $20 \mathrm{mg}$ $\mathrm{N}-\mathrm{ZnO}$ diets had the highest $\mathrm{Zn}$ in serum while $20 \mathrm{mg} \mathrm{N}-\mathrm{ZnO}$ was enough to record the highest contents of $\mathrm{Ca}$ and $\mathrm{P}$. The present data are in agreement with those obtained by Pei et al. (2018) who reported 
broiler, zinc oxide nano particle, nutrients retention, meat quality, serum parameters

that serum $\mathrm{Zn}$ was increased when pigs fed basal diet supplemented with 150 and $300 \mathrm{mg} \mathrm{N}-\mathrm{ZnO}$ or 450 and $3000 \mathrm{mg} \mathrm{I}-$ $\mathrm{ZnO}$ for 21 days. Moreover, El-Katcha et al. (2017) observed that replacing the I$\mathrm{ZnO}$ with lower levels of $\mathrm{N}-\mathrm{ZnO}$ in broiler diets increased blood serum $\mathrm{Ca}$ or $\mathrm{P}$ compared with the basal or I-ZnO diets. Furthermore, Li et al. (2016) revealed that serum $\mathrm{Zn}$ concentration of weaning piglet was increased by $120 \mathrm{mg} \mathrm{N}-\mathrm{ZnO}$ compared with 80 and $120 \mathrm{mg} \mathrm{I-ZnO}$.

\section{Meat nutrients composition:}

The effect of $\mathrm{N}-\mathrm{ZnO}$ on the chemical composition and minerals content of breast and thigh meats was similar and significant ( $\mathrm{P} \leq 0.05$ and 0.01 ) except for NFE of breast meat (Tables 4 and 5). Diets supplemented with different levels of $\mathrm{N}-\mathrm{ZnO}$ decreased moisture and crude fat and increased crude protein and ash and minerals content in breast and thigh meats. The lowest significant moisture and crude fat percentages were recorded by $\mathrm{N}-\mathrm{ZnO}$ levels (40 and $20 \mathrm{mg}$ ) and $20 \mathrm{mg}$, respectively, in comparison with the control. In contrast, a significant increase $(\mathrm{P} \leq 0.01)$ in meat crude protein, ash, $\mathrm{Ca}$ and $\mathrm{P}$ percentages and $\mathrm{Zn}(\mathrm{ppm})$ were observed and $20 \mathrm{mg} \mathrm{N}-\mathrm{ZnO} / \mathrm{kg}$ of diet recorded the highest values compared with the control.

In agreement with the present results, Ramiah et al. (2019) established that thigh muscle $\mathrm{Zn}$ content was increased with reducing dietary $\mathrm{N}-\mathrm{ZnO}$ level from $100 \mathrm{mg}$ to 60 and $40 \mathrm{mg} / \mathrm{kg}$ of broiler diet. Also, Esfahani et al. (2015) found that a mixture of $50 \mathrm{~N}-\mathrm{ZnO}+2$ Curcuma longa $/ \mathrm{kg}$ of broiler diet decreased humidity and crude fat and increased the crude protein of breast and thigh meat, resulted in improved carcass quality. Similar results were observed by Selim et al. (2014) who noticed that supplementation of $\mathrm{N}-\mathrm{ZnO}$ (40 and $80 \mathrm{mg} / \mathrm{kg}$ ) to broiler diet significantly increased muscles $\mathrm{Zn}$ content by 41.4 and $10.6 \%$ relatively with $\mathrm{ZnSO}_{4}$ and $\mathrm{Zn}$ methionine as well as reduced total lipids contents especially with the high $\mathrm{Zn}$ level (80 mg). On the other hand, muscles $\mathrm{Zn}$ content was the highest with the supplementation of $15 \mathrm{ppm} \mathrm{I}-\mathrm{ZnO}$ to broiler diet and this was significantly different with zero and $0.03 \mathrm{ppm} \mathrm{N}-\mathrm{Zn} / \mathrm{kg}$ (Sahoo et al., 2014).

\section{Tibia minerals:}

Birds fed 40 and $20 \mathrm{mg} \mathrm{N}-\mathrm{ZnO}$ diets were significantly higher $(\mathrm{P} \leq 0.01)$ in tibia $\mathrm{Ca}$ percentages compared with $100 \mathrm{mg}$ of I$\mathrm{ZnO}$ or $\mathrm{N}-\mathrm{ZnO}$ (Table 6). Also, tibia $\mathrm{P}$ percentages were significantly increased $(\mathrm{P} \leq 0.01)$ with chicks fed $20 \mathrm{mg} \mathrm{N}-\mathrm{ZnO}$ while the highest $(\mathrm{P} \leq 0.01) \mathrm{Zn}$ was recorded by birds fed 60,40 and $20 \mathrm{mg} \mathrm{N}-\mathrm{ZnO}$ diets compared with the control. The increase in the crude protein and ash of meat, as well as the minerals ( $\mathrm{Ca}, \mathrm{P}$ and $\mathrm{Zn})$ in meat and tibia, is due to increasing the same nutrients in blood serum and to improving their digestibility. The results of the current study agree with those reported by Ibrahim et al. (2017) who showed that the highest tibia $\mathrm{Zn}$ content was recorded with diets supplemented with $\mathrm{N}-\mathrm{ZnO}$ compared with that supplemented with $\mathrm{I}-\mathrm{ZnO}$ of broiler chicks. Similarly, tibia $\mathrm{Zn}$ content was significantly higher with the addition of 80 $\mathrm{mg} \mathrm{N}-\mathrm{Zn} / \mathrm{kg}$ to broiler diet in comparison with $80 \mathrm{mg}$ Zn-sulphate or the unsupplemented control (Mohammadi et al., 2015). Furthermore, Sahoo et al. (2014) stated that $\mathrm{N}-\mathrm{ZnO}$ (0.06 ppm) 
Faten A. M. Attia et al.

significantly increased $\mathrm{Zn}$ content of tibia bone compared with $\mathrm{I}_{-} \mathrm{ZnSO}_{4}$ and $\mathrm{Zn}$ Methionine. Similar results were reported in laying hens where Abedini et al. (2017) found that $80 \mathrm{mg}$ of $\mathrm{N}-\mathrm{ZnO}$ increased tibia Zn deposition.

\section{Nitrogen and minerals retention:}

Diets supplemented with $\mathrm{N}-\mathrm{ZnO}$ increased the retention percentages of $\mathrm{N}, \mathrm{Ca}, \mathrm{P}$ and $\mathrm{Zn}$ compared with the control. This retention increment was significant $(\mathrm{P} \leq 0.05)$ with $\mathrm{N}, \mathrm{Ca}$ and $\mathrm{P}$ (Table 6). Birds fed $40 \mathrm{mg} \mathrm{N}-\mathrm{ZnO}$ exhibited the highest $\mathrm{N}$, $\mathrm{Ca}, \mathrm{P}$ and $\mathrm{Zn}$ retention percentages compared with those fed the control which recorded the lowest percentages. In harmony with the current data, Ibrahim et al. (2017) on broilers and Tsai et al. (2016) on laying hens concluded that $\mathrm{Zn}$ retention was significantly increased by $\mathrm{N}-\mathrm{ZnO}$ supplementation compared with $\mathrm{I}-\mathrm{ZnO}$ because of its higher bioavailability. Also, Yan and Waldroup (2006) reported that $\mathrm{Zn}$ excretion could be reduced in the excreta by the supplementation of $\mathrm{N}-\mathrm{Zn}$ to poultry diets. Similar results were reported with pigs, supplementation of 150 and $300 \mathrm{mg}$ $\mathrm{N}-\mathrm{ZnO}$ (Pei et al., 2018) or $800 \mathrm{mg} \mathrm{N}-\mathrm{ZnO}$ $/ \mathrm{kg}$ of diet (Wang et al., 2018) decreased fecal $\mathrm{Zn}$ excretion compared with $\mathrm{I}-\mathrm{ZnO}$.

CONCLUSION
It could be concluded that the
improvements in studied criteria may be
related to more bio-available $\mathrm{Zn}$ resulted
from the new physicochemical properties
of $\mathrm{N}-\mathrm{ZnO}$ particles. Low levels
supplementation of $\mathrm{N}-\mathrm{ZnO}$ to broiler diets
was more efficient than high levels. Diets
supplemented with 40 or $20 \mathrm{mg} \mathrm{N}-\mathrm{ZnO} / \mathrm{kg}$
improved breast and thigh meats quality,
enhanced immune enzymes and, increased
blood serum and tibia mineral contents.
Also, N-ZnO increased the retention of
nitrogen, Ca, $\mathrm{P}$ and $\mathrm{Zn}$, decreasing their
excretion, which reduced environmental
pollution. Further studies are suggested to
explore the absorption mechanism,
metabolic pathways, toxicological levels
and residues in tissues of $\mathrm{N}-\mathrm{Zn}$.


broiler, zinc oxide nano particle, nutrients retention, meat quality, serum parameters

Table (1): Formula and chemical analysis (determined and calculated) _of the experimental basal diets.

\begin{tabular}{|c|c|c|c|}
\hline Ingredients (\%) & $\begin{array}{l}\text { Starter } \\
(0-3 w k)\end{array}$ & $\begin{array}{l}\text { Grower } \\
(3-5 w k)\end{array}$ & $\begin{array}{c}\text { Finisher } \\
\left(6^{\text {th }} w k\right)\end{array}$ \\
\hline Yellow corn & 57.00 & 60.60 & 64.90 \\
\hline Soybean meal (44\%CP) & 30.00 & 27.00 & 24.31 \\
\hline Corn gluten meal $(60 \% \mathrm{CP})$ & 6.70 & 5.00 & 3.00 \\
\hline Veget.oil (Soybean +sun flower) & 1.82 & 3.01 & 3.92 \\
\hline Limestone & 1.24 & 1.07 & 1.00 \\
\hline Di-calcium phosphate & 1.68 & 1.57 & 1.40 \\
\hline Mineral premix $(\mathrm{Zn} \text { free })^{1}$ & 0.25 & 0.25 & 0.25 \\
\hline Vitamin premix ${ }^{2}$ & 0.25 & 0.30 & 0.25 \\
\hline Sodium chloride & 0.40 & 0.50 & 0.37 \\
\hline DL- Methionine & 0.23 & 0.21 & 0.28 \\
\hline L-Lysine & 0.33 & 0.29 & 0.22 \\
\hline Choline chloride & 0.10 & 0.20 & 0.10 \\
\hline Total & 100.00 & 100.00 & 100.00 \\
\hline \multicolumn{4}{|c|}{ Chemical calculated values ( according to NRC, 1994) } \\
\hline Metabolizable energy (Kcal/kg) & 3000.64 & 3100.80 & 3200.26 \\
\hline Crude protein, $\%$ & 22.07 & 20.02 & 18.02 \\
\hline Lysine, \% & 1.321 & 1.196 & 1.052 \\
\hline Methionine, \% & 0.610 & 0.553 & 0.582 \\
\hline Methionine + Cystine, \% & 0.984 & 0.896 & 0.822 \\
\hline Calcium, $\%$ & 0.939 & 0.842 & 0.771 \\
\hline A. Phosphorous, $\%$ & 0.450 & 0.422 & 0.384 \\
\hline Zinc (ppm) & 26.15 & 24.91 & 23.79 \\
\hline \multicolumn{4}{|l|}{ Chemical determined analysis \% } \\
\hline Moisture & 8.66 & 8.97 & 8.95 \\
\hline Crude protein & 21.65 & 19.87 & 17.58 \\
\hline Crude fiber & 3.65 & 3.44 & 3.15 \\
\hline Ether extract & 4.97 & 5.71 & 6.76 \\
\hline Crude ash & 5.60 & 5.61 & 4.91 \\
\hline Nitrogen free extract & 55.47 & 56.40 & 58.65 \\
\hline
\end{tabular}

${ }^{1)}$ Each $1 \mathrm{~kg}$ of vitamin mixture contained: $10.000 .000 \mathrm{IU}$ vit. A, 5.000.000 IU vit. D3, $80.000 \mathrm{mg}$ vit. E, $3.000 \mathrm{mg}$ vit. K3, $3.000 \mathrm{mg}$ vit. B1, $9.000 \mathrm{mg}$ vit. B2, $4.000 \mathrm{mg}$ vit. B6, $20 \mathrm{mg}$ vit. B12, $15.000 \mathrm{mg}$ pantothenic acid, $60.000 \mathrm{mg}$ Nicotinic acid, $2.000 \mathrm{mg}$ Folic acid and $150 \mathrm{mg}$ Biotin.

${ }^{2)}$ Each $2 \mathrm{~kg}$ of minerals mixture contained: $500.000 \mathrm{mg}$ choline chloride, $150.000 \mathrm{mg} \mathrm{Cu}, 1.000 \mathrm{mg}$ I; $40.000 \mathrm{mg} \mathrm{Fe}, 100.000 \mathrm{mg}$ Mn. and $350 \mathrm{mg} \mathrm{Se}$. 
Table (2): Effect of dietary nano zinc oxide $(\mathrm{N}-\mathrm{ZnO})$ on blood serum constituents of broiler chicks at 42 days of age $(\mathrm{M} \pm \mathrm{SE})$.

\begin{tabular}{|c|c|c|c|c|c|c|c|c|}
\hline Treatments & $\begin{array}{l}\text { Total } \\
\text { protein } \\
(\mathrm{g} / \mathrm{dL})\end{array}$ & $\begin{array}{l}\text { Albumin } \\
(\mathrm{g} / \mathrm{dL})\end{array}$ & $\begin{array}{c}\text { Creatinine } \\
(\mathbf{m g} / \mathbf{d L})\end{array}$ & $\begin{array}{l}\text { Uric acid } \\
\text { (mg/dL) }\end{array}$ & $\begin{array}{c}\text { Triglyceride } \\
\text { (mg/dL) }\end{array}$ & $\begin{array}{c}\text { Cholesterol } \\
(\mathbf{m g} / \mathbf{d L})\end{array}$ & $\begin{array}{c}\text { HDL } \\
(\mathbf{m g} / \mathbf{d L})\end{array}$ & $\begin{array}{c}\text { LDL } \\
(\mathbf{m g} / \mathbf{d L})\end{array}$ \\
\hline $\begin{array}{c}\text { Control } \\
100 \mathrm{I}-\mathrm{ZnO}^{*}\end{array}$ & $3.62 \pm 0.10$ & $1.43^{\mathrm{d}} \pm 0.09$ & $3.02^{\mathrm{a}} \pm 0.05$ & $8.64^{\mathrm{a}} \pm 0.28$ & $67.49^{\mathrm{a}} \pm 1.80$ & $155.76 \pm 1.53$ & $50.11^{\mathrm{d}} \pm 1.84$ & $40.57^{\mathrm{b}} \pm 1.30$ \\
\hline $100 \mathrm{~N}-\mathrm{ZnO}{ }^{* *}$ & $3.84 \pm 0.07$ & $2.01^{\mathrm{c}} \pm 0.13$ & $2.79^{\mathrm{ab}} \pm 0.09$ & $7.87^{\mathrm{b}} \pm 0.28$ & $62.70^{\mathrm{ab}} \pm 2.04$ & $154.60 \pm 1.36$ & $56.45^{\mathrm{c}} \pm 1.73$ & $43.26^{\mathrm{ab}} \pm 1.12$ \\
\hline $80 \mathrm{~N}-\mathrm{ZnO}$ & $3.66 \pm 0.06$ & $1.96^{\mathrm{c}} \pm 0.17$ & $2.61^{\mathrm{bc}} \pm 0.11$ & $7.40^{\mathrm{bc}} \pm 0.26$ & $58.97^{b c} \pm 2.36$ & $150.67 \pm 1.73$ & $59.17^{b c} \pm 1.35$ & $44.08^{\mathrm{ab}} \pm 1.79$ \\
\hline $60 \mathrm{~N}-\mathrm{ZnO}$ & $3.80 \pm 0.09$ & $2.21^{\mathrm{bc}} \pm 0.17$ & $2.38^{\mathrm{c}} \pm 0.09$ & $6.83^{c} \pm 0.19$ & $56.25^{\mathrm{c}} \pm 1.56$ & $151.19 \pm 2.11$ & $62.67^{\mathrm{b}} \pm 1.96$ & $46.32^{\mathrm{a}} \pm 1.48$ \\
\hline $40 \mathrm{~N}-\mathrm{ZnO}$ & $3.84 \pm 0.06$ & $2.51^{\mathrm{ab}} \pm 0.14$ & $1.87^{\mathrm{d}} \pm 0.10$ & $5.12^{\mathrm{d}} \pm 0.24$ & $49.71^{\mathrm{d}} \pm 2.35$ & $152.79 \pm 1.26$ & $68.29^{\mathrm{a}} \pm 1.58$ & $47.62^{\mathrm{a}} \pm 2.32$ \\
\hline $20 \mathrm{~N}-\mathrm{ZnO}$ & $3.74 \pm 0.06$ & $2.65^{\mathrm{a}} \pm 0.09$ & $1.63^{\mathrm{d}} \pm 0.10$ & $5.00^{\mathrm{d}} \pm 0.33$ & $48.56^{\mathrm{d}} \pm 2.17$ & $150.20 \pm 2.94$ & $69.50^{\mathrm{a}} \pm 2.33$ & $48.07^{\mathrm{a}} \pm 1.48$ \\
\hline Sig. & NS & $\mathrm{P} \leq 0.01$ & $\mathrm{P} \leq 0.01$ & $\mathrm{P} \leq 0.01$ & $\mathrm{P} \leq 0.01$ & NS & $\mathrm{P} \leq 0.01$ & $\mathrm{P} \leq 0.05$ \\
\hline
\end{tabular}


Table (3): Effect of dietary nano zinc oxide $(\mathrm{N}-\mathrm{ZnO})$ on blood serum enzymes and minerals of broiler chicks at 42 days of age (M $\pm \mathrm{SE})$.

\begin{tabular}{|c|c|c|c|c|c|c|c|c|c|}
\hline \multirow[b]{2}{*}{ Treatments } & \multicolumn{6}{|c|}{ Enzymes } & \multicolumn{3}{|c|}{ Minerals } \\
\hline & $\begin{array}{l}\text { AST } \\
\text { (U/I) }\end{array}$ & $\begin{array}{l}\text { ALT } \\
\text { (U/l) }\end{array}$ & $\begin{array}{c}\mathbf{A L P} \\
(\mathbf{U} / \mathbf{L})\end{array}$ & $\begin{array}{c}\text { LDH } \\
\text { (U/L) }\end{array}$ & $\begin{array}{c}\text { SOD } \\
(\mathrm{U} / \mathrm{ml})\end{array}$ & $\begin{array}{c}\text { MDA } \\
(\mathrm{nmol} / \mathrm{ml})\end{array}$ & $\begin{array}{l}\text { Calcium } \\
\text { (mg/dL) }\end{array}$ & $\begin{array}{c}\text { Phosphorus } \\
\text { (mg/dL) }\end{array}$ & $\begin{array}{c}\text { Zinc } \\
(\mu \mathrm{g} / \mathrm{dL})\end{array}$ \\
\hline $\begin{array}{l}\text { Control } \\
100 \mathrm{I}-\mathrm{ZnO}\end{array}$ & $\begin{array}{c}177.48^{\mathrm{a}} \\
\pm 2.21\end{array}$ & $\begin{array}{r}7.85^{\mathrm{a}} \\
\pm 0.13\end{array}$ & $\begin{array}{c}331.33^{\mathrm{a}} \\
\pm 3.75\end{array}$ & $\begin{array}{c}2992.00^{\mathrm{b}} \\
\pm 63.15\end{array}$ & $\begin{array}{c}160.26^{\mathrm{d}} \\
\pm 2.34\end{array}$ & $\begin{array}{l}3.01^{\mathrm{a}} \\
\pm 0.06\end{array}$ & $\begin{array}{l}9.10^{\mathrm{e}} \\
\pm 0.23\end{array}$ & $\begin{array}{l}4.72^{\mathrm{e}} \\
\pm 0.16\end{array}$ & $\begin{array}{l}98.53^{\mathrm{e}} \\
\pm 3.05\end{array}$ \\
\hline $100 \mathrm{~N}-\mathrm{ZnO}{ }^{* *}$ & $\begin{array}{c}173.57^{\mathrm{ab}} \\
\pm 2.41\end{array}$ & $\begin{array}{r}6.93^{\mathrm{b}} \\
\pm 0.20\end{array}$ & $\begin{array}{c}324.22^{\mathrm{ab}} \\
\pm 2.80\end{array}$ & $\begin{array}{c}3078.38^{\mathrm{ab}} \\
\pm 61.69\end{array}$ & $\begin{array}{c}165.16^{\mathrm{cd}} \\
\pm 2.51\end{array}$ & $\begin{array}{l}2.86^{\mathrm{ab}} \\
\pm 0.02\end{array}$ & $\begin{array}{l}9.51^{\mathrm{de}} \\
\pm 0.25\end{array}$ & $\begin{array}{l}5.30^{\text {de }} \\
\pm 0.27\end{array}$ & $\begin{array}{c}106.93^{\mathrm{de}} \\
\pm 3.42\end{array}$ \\
\hline $80 \mathrm{~N}-\mathrm{ZnO}$ & $\begin{array}{c}168.97^{\mathrm{bc}} \\
\pm 2.06\end{array}$ & $\begin{array}{l}6.43^{\mathrm{bc}} \\
\pm 0.29\end{array}$ & $\begin{array}{c}318.81^{\mathrm{bc}} \\
\pm 4.10\end{array}$ & $\begin{array}{c}3117.50^{\mathrm{ab}} \\
\pm 58.53\end{array}$ & $\begin{array}{c}167.44^{\mathrm{bc}} \\
\pm 2.49\end{array}$ & $\begin{array}{l}2.71^{\mathrm{bc}} \\
\pm 0.06\end{array}$ & $\begin{array}{l}9.90^{\text {cd }} \\
\pm 0.26\end{array}$ & $\begin{array}{l}5.81^{\text {cd }} \\
\pm 0.24\end{array}$ & $\begin{array}{c}113.94^{\text {bc }} \\
\pm 3.09\end{array}$ \\
\hline $60 \mathrm{~N}-\mathrm{ZnO}$ & $\begin{array}{c}165.32^{\mathrm{cd}} \\
\pm 2.45\end{array}$ & $\begin{array}{l}5.90^{\text {cd }} \\
\pm 0.37\end{array}$ & $\begin{array}{c}313.66^{\mathrm{bcd}} \\
\pm 3.16\end{array}$ & $\begin{array}{c}3186.69^{\mathrm{a}} \\
\pm 36.71\end{array}$ & $\begin{array}{c}172.98^{\mathrm{b}} \\
\pm 2.18\end{array}$ & $\begin{array}{l}2.56^{\mathrm{c}} \\
\pm 0.10\end{array}$ & $\begin{array}{c}10.51^{\mathrm{bc}} \\
\pm 0.25\end{array}$ & $\begin{array}{l}6.29^{\mathrm{bc}} \\
\pm 0.21\end{array}$ & $\begin{array}{c}122.18^{\mathrm{b}} \\
\pm 3.20\end{array}$ \\
\hline $40 \mathrm{~N}-\mathrm{ZnO}$ & $\begin{array}{c}161.05^{\mathrm{d}} \\
\pm 3.29\end{array}$ & $\begin{array}{l}5.37^{\mathrm{de}} \\
\pm 0.28\end{array}$ & $\begin{array}{c}307.99^{\mathrm{cd}} \\
\pm 3.91\end{array}$ & $\begin{array}{c}3206.50^{\mathrm{a}} \\
\pm 39.59\end{array}$ & $\begin{array}{c}179.50^{\mathrm{a}} \\
\pm 2.13\end{array}$ & $\begin{array}{l}2.36^{\mathrm{d}} \\
\pm 0.07\end{array}$ & $\begin{array}{c}11.07^{\mathrm{ab}} \\
\pm 0.28\end{array}$ & $\begin{array}{l}6.69^{\mathrm{ab}} \\
\pm 0.27\end{array}$ & $\begin{array}{c}135.49^{\mathrm{a}} \\
\pm 2.94\end{array}$ \\
\hline $20 \mathrm{~N}-\mathrm{ZnO}$ & $\begin{array}{c}160.29^{\mathrm{d}} \\
\pm 3.16\end{array}$ & $\begin{array}{l}5.12^{\mathrm{e}} \\
\pm 0.26\end{array}$ & $\begin{array}{c}305.57^{\mathrm{d}} \\
\pm 4.20\end{array}$ & $\begin{array}{c}3212.44^{\mathrm{a}} \\
\pm 50.17\end{array}$ & $\begin{array}{c}180.10^{\mathrm{a}} \\
\pm 2.25\end{array}$ & $\begin{array}{l}2.26^{\mathrm{d}} \\
\pm 0.05\end{array}$ & $\begin{array}{l}11.29^{\mathrm{a}} \\
\pm 0.19\end{array}$ & $\begin{array}{c}6.97^{\mathrm{a}} \\
\pm 0.20\end{array}$ & $\begin{array}{c}137.95^{\mathrm{a}} \\
\pm 2.77\end{array}$ \\
\hline Sig. & $\mathrm{P} \leq 0.01$ & $\mathrm{P} \leq 0.01$ & $\mathrm{P} \leq 0.01$ & $\mathrm{P} \leq 0.05$ & $\mathrm{P} \leq 0.01$ & $\mathrm{P} \leq 0.01$ & $\mathrm{P} \leq 0.01$ & $\mathrm{P} \leq 0.01$ & $\mathrm{P} \leq 0.01$ \\
\hline
\end{tabular}

${ }^{\mathrm{a}-\mathrm{e}}$ means within each column followed by different letters differ significantly, ${ }^{*} \mathrm{I}-\mathrm{ZnO}=$ inorganic zinc oxide and ${ }^{* *} \mathrm{~N}-\mathrm{ZnO}=$ nano zinc oxide . 
Table (4): Effect of dietary nano zinc oxide (N-ZnO) on breast meat chemical composition (\%) of broiler chicks at 42 days of age (M $\pm \mathrm{SE})$.

\begin{tabular}{|c|c|c|c|c|c|c|c|c|}
\hline \multirow[t]{2}{*}{ Treatments } & \multicolumn{7}{|c|}{ Percentage (\%) } & \multirow{2}{*}{$\begin{array}{c}\text { Zinc } \\
(\mathbf{p p m})\end{array}$} \\
\hline & Moisture & Crude protein & Crude fat & Crude ash & NFE & Calcium & Phosphorus & \\
\hline $\begin{array}{l}\text { Control } \\
100 \text { I-ZnO* }\end{array}$ & $6.99^{\mathrm{a}} \pm 0.13$ & $54.88^{\mathrm{e}} \pm 0.13$ & $33.74^{\mathrm{a}} \pm 0.25$ & $3.51^{\mathrm{c}} \pm 0.13$ & $0.68 \pm 0.06$ & $0.469^{f} \pm 0.005$ & $0.668^{\mathrm{f}} \pm 0.006$ & $211.88^{f} \pm 2.13$ \\
\hline $100 \mathrm{~N}-\mathrm{ZnO} \mathrm{O}^{* *}$ & $6.96^{\mathrm{ab}} \pm 0.14$ & $56.22^{\mathrm{d}} \pm 0.26$ & $32.20^{\mathrm{b}} \pm 0.16$ & $3.96^{\mathrm{b}} \pm 0.11$ & $0.66 \pm 0.06$ & $0.516^{\mathrm{e}} \pm 0.006$ & $0.726^{\mathrm{e}} \pm 0.009$ & $219.75^{\mathrm{e}} \pm 1.74$ \\
\hline $80 \mathrm{~N}-\mathrm{ZnO}$ & $6.64^{\mathrm{abc}} \pm 0.13$ & $57.12^{\mathrm{c}} \pm 0.20$ & $31.41^{\mathrm{c}} \pm 0.23$ & $4.10^{\mathrm{ab}} \pm 0.14$ & $0.73 \pm 0.03$ & $0.558^{\mathrm{d}} \pm 0.005$ & $0.764^{\mathrm{d}} \pm 0.007$ & $230.38^{\mathrm{d}} \pm 1.19$ \\
\hline $60 \mathrm{~N}-\mathrm{ZnO}$ & $6.63^{\mathrm{abc}} \pm 0.16$ & $57.52^{\mathrm{c}} \pm 0.19$ & $31.05^{c} \pm 0.25$ & $4.15^{\mathrm{ab}} \pm 0.15$ & $0.65 \pm 0.03$ & $0.604^{c} \pm 0.006$ & $0.804^{\mathrm{c}} \pm 0.008$ & $236.25^{\mathrm{c}} \pm 1.06$ \\
\hline $40 \mathrm{~N}-\mathrm{ZnO}$ & $6.50^{\mathrm{bc}} \pm 0.22$ & $58.86^{\mathrm{b}} \pm 0.16$ & $29.67^{\mathrm{d}} \pm 0.18$ & $4.26^{\mathrm{ab}} \pm 0.09$ & $0.71 \pm 0.04$ & $0.656^{\mathrm{b}} \pm 0.005$ & $0.825^{\mathrm{b}} \pm 0.006$ & $245.13^{\mathrm{b}} \pm 1.16$ \\
\hline $20 \mathrm{~N}-\mathrm{ZnO}$ & $6.25^{\mathrm{c}} \pm 0.11$ & $59.90^{\mathrm{a}} \pm 0.12$ & $28.67^{\mathrm{e}} \pm 0.18$ & $4.46^{\mathrm{a}} \pm 0.14$ & $0.71 \pm 0.04$ & $0.706^{\mathrm{a}} \pm 0.007$ & $0.858^{\mathrm{a}} \pm 0.008$ & $258.50^{\mathrm{a}} \pm 1.20$ \\
\hline Sig. & $\mathrm{P} \leq 0.05$ & $\mathrm{P} \leq 0.01$ & $\mathrm{P} \leq 0.01$ & $\mathrm{P} \leq 0.01$ & NS & $\mathrm{P} \leq 0.01$ & $\mathrm{P} \leq 0.01$ & $\mathrm{P} \leq 0.01$ \\
\hline
\end{tabular}

${ }^{\mathrm{a}-\mathrm{f}}$ means within each column followed by different letters differ significantly, $\mathrm{NS}=$ Non significant, ${ }^{*} \mathrm{I}-\mathrm{ZnO}=$ inorganic zinc oxide and ${ }^{* *} \mathrm{~N}-\mathrm{ZnO}=$ nano zinc oxide .

Table (5): Effect of dietary nano zinc oxide (N-ZnO) particles on thigh meat chemical composition (\%) of broiler chicks at 42 days of age $(\mathrm{M} \pm \mathrm{SE})$.

\begin{tabular}{|c|c|c|c|c|c|c|c|c|}
\hline \multirow[t]{2}{*}{ Treatments } & \multicolumn{7}{|c|}{ Percentage (\%) } & \multirow{2}{*}{ Zinc (ppm) } \\
\hline & Moisture & Crude protein & Crude fat & Crude ash & NFE & Calcium & Phosphorus & \\
\hline $\begin{array}{l}\text { Control } \\
100 \text { I-ZnO* }\end{array}$ & $6.00^{\mathrm{a}} \pm 0.12$ & $50.75^{f} \pm 0.16$ & $39.01^{\mathrm{a}} \pm 0.19$ & $2.63^{\mathrm{c}} \pm 0.18$ & $1.48^{\mathrm{a}} \pm 0.10$ & $0.423^{\mathrm{e}} \pm 0.005$ & $0.605^{\mathrm{e}} \pm 0.006$ & $417.25^{\mathrm{e}} \pm 3.94$ \\
\hline $100 \mathrm{~N}-\mathrm{ZnO}{ }^{* *}$ & $5.96^{\mathrm{a}} \pm 0.12$ & $51.75^{\mathrm{e}} \pm 0.16$ & $38.15^{\mathrm{b}} \pm 0.21$ & $2.88^{b c} \pm 0.13$ & $1.39^{\mathrm{ab}} \pm 0.09$ & $0.431^{\mathrm{e}} \pm 0.006$ & $0.621^{\mathrm{e}} \pm 0.008$ & $436.50^{\mathrm{d}} \pm 1.55$ \\
\hline $80 \mathrm{~N}-Z n O$ & $5.73^{\mathrm{ab}} \pm 0.14$ & $53.00^{\mathrm{d}} \pm 0.19$ & $36.85^{\mathrm{c}} \pm 0.21$ & $3.00^{\mathrm{bc}} \pm 0.00$ & $1.28^{\mathrm{ab}} \pm 0.06$ & $0.463^{\mathrm{d}} \pm 0.006$ & $0.649^{\mathrm{d}} \pm 0.004$ & $444.75^{\mathrm{c}} \pm 1.67$ \\
\hline $60 \mathrm{~N}-\mathrm{ZnO}$ & $5.56^{\mathrm{abc}} \pm 0.14$ & $54.08^{c} \pm 0.30$ & $35.50^{\mathrm{d}} \pm 0.19$ & $3.25^{\mathrm{ab}} \pm 0.16$ & $1.40^{\mathrm{ab}} \pm 0.06$ & $0.518^{c} \pm 0.013$ & $0.668^{c} \pm 0.005$ & $457.75^{\mathrm{b}} \pm 0.90$ \\
\hline $40 \mathrm{~N}-\mathrm{ZnO}$ & $5.49^{b c} \pm 0.19$ & $54.90^{\mathrm{b}} \pm 0.40$ & $34.75^{\mathrm{e}} \pm 0.16$ & $3.52^{\mathrm{a}} \pm 0.20$ & $1.23^{\mathrm{b}} \pm 0.04$ & $0.571^{\mathrm{b}} \pm 0.007$ & $0.688^{\mathrm{b}} \pm 0.008$ & $462.88^{\mathrm{b}} \pm 1.62$ \\
\hline $20 \mathrm{~N}-\mathrm{ZnO}$ & $5.22^{c} \pm 0.14$ & $55.99^{\mathrm{a}} \pm 0.19$ & $33.63^{f} \pm 0.18$ & $3.61^{\mathrm{a}} \pm 0.18$ & $1.39 \mathrm{a}^{\mathrm{b}} \pm 0.07$ & $0.618^{\mathrm{a}} \pm 0.011$ & $0.729^{\mathrm{a}} \pm 0.005$ & $493.25^{\mathrm{a}} \pm 2.30$ \\
\hline Sig. & $\mathrm{P} \leq 0.01$ & $\mathrm{P} \leq 0.01$ & $\mathrm{P} \leq 0.01$ & $\mathrm{P} \leq 0.01$ & $\mathrm{P} \leq 0.05$ & $\mathrm{P} \leq 0.01$ & $\mathrm{P} \leq 0.01$ & $\mathrm{P} \leq 0.01$ \\
\hline
\end{tabular}

${ }^{\mathrm{a}-\mathrm{f}}$ means within each column followed by different letters differ significantly, ${ }^{*} \mathrm{I}-\mathrm{ZnO}=$ inorganic Znic oxide and ${ }^{* * *} \mathrm{~N}-\mathrm{ZnO}=$ nano zinc oxide . 
Table (6): Effect of dietary nano zinc oxide $(\mathrm{N}-\mathrm{ZnO})$ particles on tibia minerals and retention percentages of nitrogen, calcium, phosphorus and zinc of broiler chicks at 42 days of age $(\mathrm{M} \pm \mathrm{SE})$.

\begin{tabular}{|c|c|c|c|c|c|c|c|}
\hline \multirow{2}{*}{$\begin{array}{l}\text { Treatments } \\
\text { mg/kg diet }\end{array}$} & \multicolumn{4}{|c|}{ Retention percentage (\%) } & \multicolumn{3}{|c|}{ Tibia minerals } \\
\hline & Nitrogen & Calcium & Phosphorus & Zinc & Calcium (\%) & Phosphorus (\%) & Zinc (ppm) \\
\hline $\begin{array}{l}\text { Control } \\
100 \text { I-ZnO* }\end{array}$ & $93.84^{\mathrm{b}} \pm 0.29$ & $63.28^{\mathrm{c}} \pm 2.78$ & $69.36^{\mathrm{b}} \pm 1.94$ & $45.44 \pm 2.77$ & $31.50^{\mathrm{c}} \pm 0.28$ & $12.78^{\mathrm{e}} \pm 0.15$ & $162.69^{\mathrm{d}} \pm 0.51$ \\
\hline $100 \mathrm{~N}-\mathrm{ZnO}{ }^{* *}$ & $94.91^{\mathrm{ab}} \pm 0.28$ & $69.60^{\mathrm{bc}} \pm 2.19$ & $72.97^{\mathrm{ab}} \pm 2.48$ & $45.59 \pm 5.04$ & $32.43^{b c} \pm 0.55$ & $13.25^{\mathrm{d}} \pm 0.15$ & $165.02^{c} \pm 0.31$ \\
\hline $80 \mathrm{~N}-\mathrm{ZnO}$ & $95.38^{\mathrm{ab}} \pm 0.45$ & $73.38^{\mathrm{ab}} \pm 2.49$ & $75.78^{\mathrm{ab}} \pm 2.30$ & $45.92 \pm 2.04$ & $33.08^{\mathrm{ab}} \pm 0.31$ & $13.53^{\mathrm{cd}} \pm 0.15$ & $168.18^{\mathrm{b}} \pm 0.32$ \\
\hline $60 \mathrm{~N}-\mathrm{ZnO}$ & $94.88^{\mathrm{a}} \pm 0.61$ & $74.20^{\mathrm{ab}} \pm 2.82$ & $73.95^{\mathrm{ab}} \pm 2.88$ & $46.68 \pm 3.66$ & $33.22^{\mathrm{ab}} \pm 0.41$ & $13.87^{\mathrm{bc}} \pm 0.16$ & $170.74^{\mathrm{a}} \pm 0.39$ \\
\hline $40 \mathrm{~N}-\mathrm{ZnO}$ & $96.05^{\mathrm{a}} \pm 0.24$ & $79.38^{\mathrm{a}} \pm 0.70$ & $81.87^{\mathrm{a}} \pm 0.85$ & $48.41 \pm 4.71$ & $33.75^{\mathrm{a}} \pm 0.52$ & $14.23^{\mathrm{ab}} \pm 0.16$ & $172.07^{\mathrm{a}} \pm 0.71$ \\
\hline $20 \mathrm{~N}-\mathrm{ZnO}$ & $95.22^{\mathrm{ab}} \pm 0.76$ & $76.50^{\mathrm{ab}} \pm 4.60$ & $76.90^{\mathrm{ab}} \pm 5.05$ & $47.17 \pm 6.11$ & $33.80^{\mathrm{a}} \pm 0.34$ & $14.64^{\mathrm{a}} \pm 0.20$ & $172.20^{\mathrm{a}} \pm 0.91$ \\
\hline Sig. & $\mathrm{P} \leq 0.05$ & $\mathrm{P} \leq 0.05$ & $\mathrm{P} \leq 0.05$ & NS & $\mathrm{P} \leq 0.01$ & $\mathrm{P} \leq 0.01$ & $\mathrm{P} \leq 0.01$ \\
\hline
\end{tabular}

${ }^{\mathrm{a}-\mathrm{e}}$ means within each column followed by different letters differ significantly, $\mathrm{NS}=$ Non significant,${ }^{*} \mathrm{I}-\mathrm{ZnO}=$ inorganic zinc oxide and ${ }^{* * *} \mathrm{~N}-\mathrm{ZnO}=$ nano zinc oxide . 
Faten A. M. Attia et al.

Date: $13 / 09 / 2017$

File: $\mathrm{ZnO} 2$

Time: $02: 11: 36_{\vec{r}}$

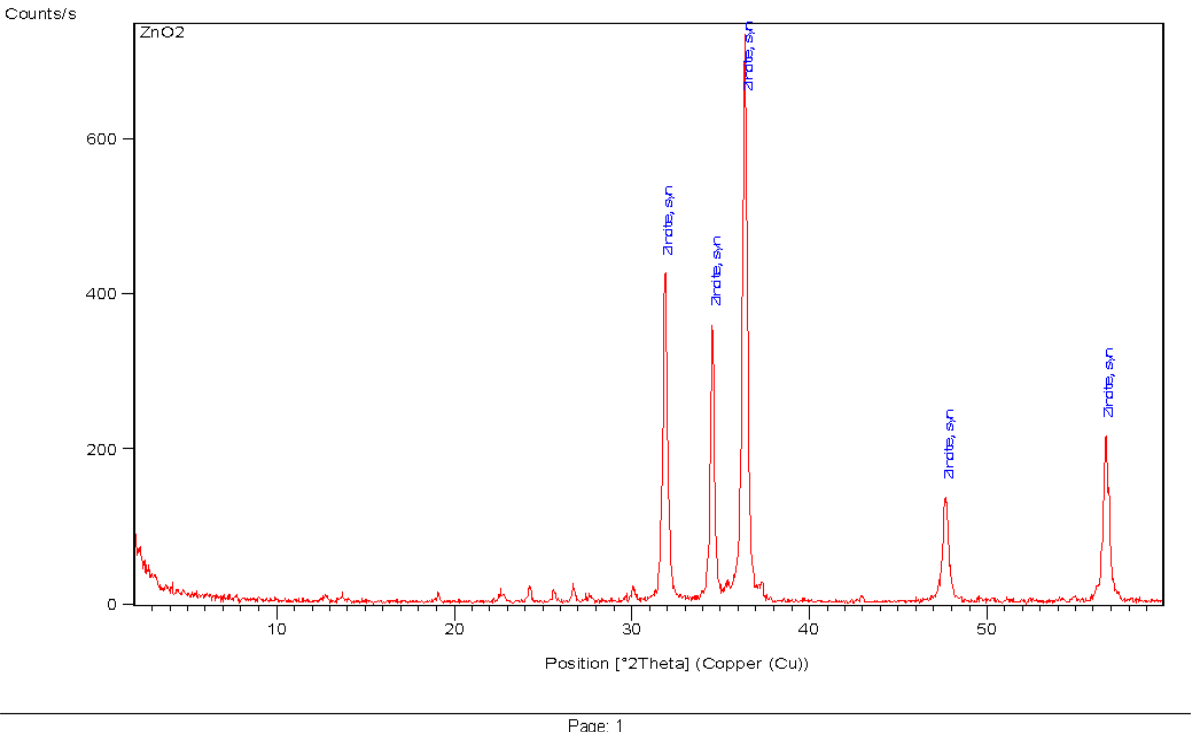

Figure(1): XRD pattern of the synthesized $\mathrm{ZnO}$ nanoparticles

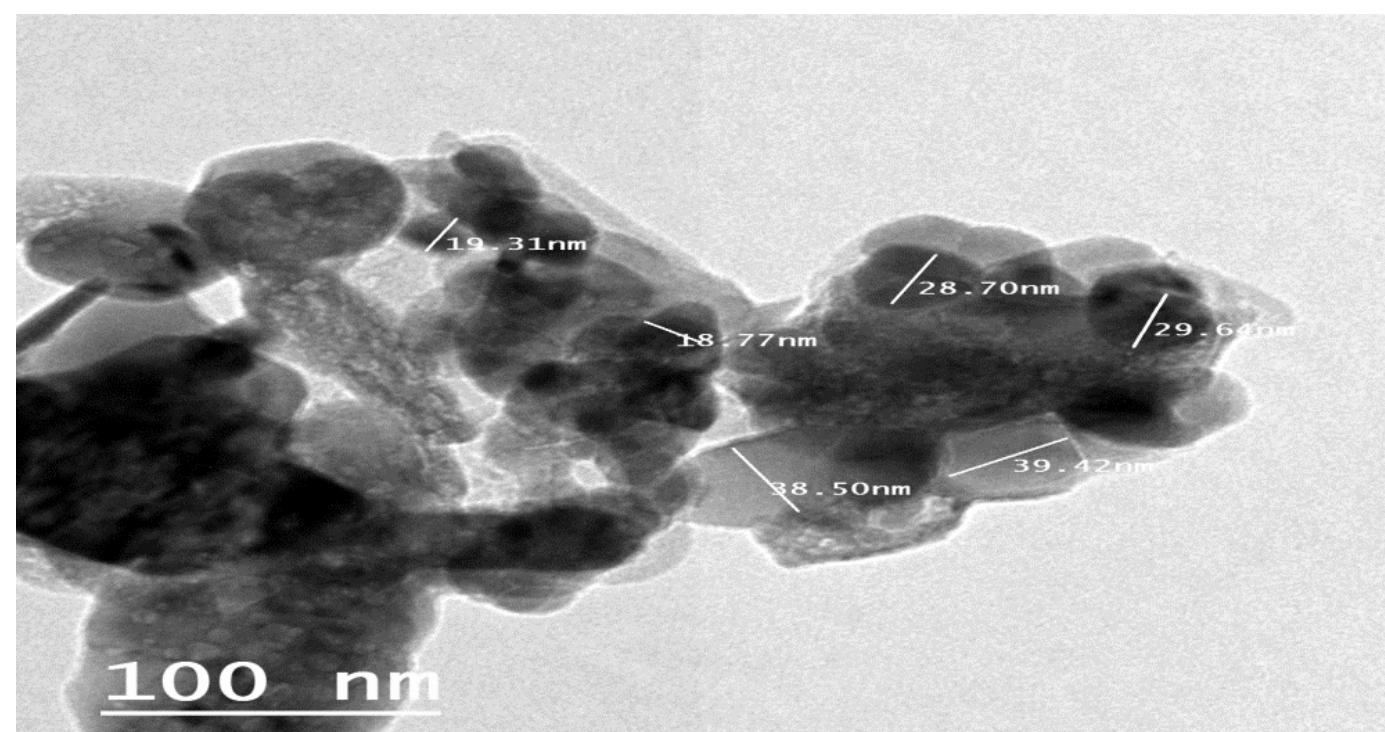

Figure (2): TEM images of the synthesized $\mathrm{ZnO}$ nanoparticles 
broiler, zinc oxide nano particle, nutrients retention, meat quality, serum parameters

\begin{tabular}{l}
\hline REFERENCES \\
Abedini, M.; Shariatmadari, F.; \\
Torshizi, M. K. and Ahmadi, H. 2017. \\
Effects of a dietary supplementation \\
with zinc oxide nanoparticles, compared \\
to zinc oxide and zinc methionine, on \\
performance, egg quality, and zinc \\
status of laying hens. Livestock \\
Sci., 203: $30-36$.
\end{tabular}

Ahmadi, F.; Ebrahimnezhad, Y.; Sis, N. M. and Ghiasi, J. 2013. The effects of zinc oxide nanoparticles on performance, digestive organs and serum lipid concentrations in broiler chickens during starter period. Int. J. Biosci., 3: 23-29.

Ahmadi, F.; Ebrahimnezjad, Y.; Ghalehkandi, J. G. and Sis, N. M. 2014. The effect of dietary zinc oxide nanoparticles on the antioxidant state and serum enzymes activity in broiler chickens during starter stage. In Int. Conf. on Biol., Civil and Environmental Engineering, BCEE. Dubai (UAE): 2628.

Al-Daraji, H. J. and Amen, M. H. 2011. Effect of dietary zinc on certain blood traits of broiler breeder chickens. Int. J. Poult. Sci., 10: 807-813.

A.O.A.C.1990. Association of Official Analytical Chemists, Official Methods of Analysis, $15^{\text {th }}$ Edition. Washington, D. C, USA.

Berg, J. M. and Shi, Y. 1996. The galvanization of biology: a growing appreciation for the roles of zinc. Sci., 271: 1081-1085.

Broom, L. J.; Miller, H. M.; Kerr, K. G. and Toplis, P. 2003. Removal of both zinc oxide and avilamycin from the post-weaning piglet diet: consequences

for performance through to

slaughter. Anim. Sci.,77: 79-84.

Case, C. L. and Carlson, M. S. 2002. Effect of feeding organic and inorganic sources of additional zinc on growth performance and zinc balance in nursery pigs. J. Anim. Sci., 80: 1917-1924.

Chand, N.; Naz, S.; Khan, A.; Khan, S. and Khan, R. U. 2014. Performance traits and immune response of broiler chicks treated with zinc and ascorbic acid supplementation during cyclic heat stress. Int. J. Biometeorol, 58: 21532157.

El-Katcha, M.; Soltan, M. A. and ElBadry, M. 2017. Effect of dietary replacement of inorganic zinc by organic or nanoparticles sources on growth performance, immune response and intestinal histopathology of broiler chicken. Alex. J. Vet. Sci., 55:129-145.

Esfahani, M.; Ahmadi, F. and Andi, M. A. 2015. The effects of different levels of Curcuma longa and zinc oxide nanoparticles on the quality traits of thigh and breast meat in broiler chickens. Int. J. Biosci. (IJB), 6 : 296302.

Fathi, M.; Haydari, M. and Tanha, T. 2016. Effects of zinc oxide nanoparticles on antioxidant status, serum enzymes activities, biochemical parameters and performance in broiler chickens. J. Live. Sci. and Tech., 4: 713.

Fodor, P.; Pólos, L.; Bezur, L. and Pungor, E. 1973. Determination of calcium, magnesium, iron and zinc in protein concentrates by atomic absorption spectrometry. Periodica 
Faten A. M. Attia et al.

Polytechnica Chemical Engineering, 18: 125-132.

Duncan, D.B., 1955. Multiple range and multiple F tests. Biometrics, 11: 1-42.

Hafez, A.; Nassef, E.; Fahmy, M.; Elsabagh, M.; Bakr, A. and Hegazi, E. 2019. Impact of dietary nano-zinc oxide on immune response and antioxidant defense of broiler chickens. Environ. Sci. Poult. Res., 1-7.

Hassan, F. A. M.; Mahmoud, R. and ElAraby, I. E. 2017. Growth performance, serum biochemical, economic evaluation and IL6 gene expression in growing rabbits fed diets supplemented with zinc nanoparticles. Zag. Vet. J., 45: 238-249.

Huang, Y. L.; Lu, L.; Luo, X. G. and Liu, B. 2007. An optimal dietary zinc level of broiler chicks fed a cornsoybean meal diet. Poult. Sci., 86: 25822589.

Huang, S; Wang, L; Liu, L; Hou, Y and Li, L. 2015. Nanotechnology in agriculture, livestock, and aquaculture in China. A review. Agronomy for Sustainable Development, Springer Verlag/EDP Sci./INRA, 35: 369-400.

Ibrahim, D.; Ali, H. A. and ElMandrawy, S. A. 2017. Effects of different zinc sources on performance, bio distribution of minerals and expression of genes related to metabolism of broiler chickens. Zag. Vet. J., 45: 292-304.

Ibs K H. and Rink L. 2003. Zinc alters immune function. The J. of Nutrition, 133: 1452S-1456S.

Kietzmann, M., and Braun, M. 2006. Effects of the zinc oxide and cod liver oil containing ointment Zincojecol in an animal model of wound healing. DTW.

Deutsche tierarztliche

Wochenschrift, 113: 331-334.

Kumar, S. S.; Venkateswarlu, P.; Rao, V. R. and Rao, G. N. 2013. Synthesis, characterization and optical properties of zinc oxide nanoparticles. Int. Nano Letters, 3: 1-6.

Li, M. Z.; Huang, J. T.; Tsai, Y. H.; Mao, S. Y.; Fu, C. M. and Lien, T. F. 2016. Nanosize of zinc oxide and the effects on zinc digestibility, growth performances, immune response and serum parameters of weanling piglets. Anim. Sci. J., 87: 1379-1385.

Mohammadi, V.; Ghazanfari, S.; Mohammadi-Sangcheshmeh, A. and Nazaran, M. H. 2015. Comparative effects of zinc-nano complexes, zincsulphate and zinc-methionine on performance in broiler chickens. Brit. Poult. Sci., 56: 486-493.

NRC.1994. Nutrient Requirements of Poultry, $9^{\text {th }}$ Rev. Ed. National Academy Press, Washington, DC., USA.

Pei, X.; Xiao, Z.; Liu, L.; Wang, G.; Tao, W.; Wang, M.; Zou, J. and Leng, D. 2018. Effects of dietary zinc oxide nanoparticles supplementation on growth performance, zinc status, intestinal morphology, microflora population, and immune response in weaned pigs. Journal of the science of food and agriculture, 99: 1366-1374.

Rai, M. and Ingle, A. 2012. Role of nanotechnology in agriculture with special reference to management of insect pests. Appl Microbiol Biotechnol. 94: 287-293.

Ramiah, S. K.; Awad, E. A.; Mookiah, S. and Idrus, Z. 2019. Effects of zinc 
broiler, zinc oxide nano particle, nutrients retention, meat quality, serum parameters

oxide nanoparticles on growth performance and concentrations of malondialdehyde, zinc in tissues, and corticosterone in broiler chickens under heat stress conditions. Poult. Sci., 0:111.

Sahoo, A.; Swain, R.K. and Mishra, S.K. 2014. Effect of inorganic, organic and nano zinc supplemented diets on bioavailability and immunity status of broilers. Int. J. of Adv. Res., 2: 828-837.

Selim, N. A.; Amira, M.; Khosht, A. R. and El-Hakim, A. A. 2014. Effect of sources and inclusion levels of zinc in broiler diets containing different vegetable oils during summer season conditions on meat quality. Int. J. Poult. Sci., 13: 619-626.

Stefanidou, M.; Maravelias, C.; Dona, A. and Spiliopoulou , C. 2006. Zinc: a multipurpose trace element. Arch Toxicol. 80: 1-9

Štenclová, H.; Karásek, F.; Št’astník, O.; Zeman, L.; Mrkvicová, E. and Pavlata, L. 2016. The effect of reduced zinc levels on performance parameters of broiler chickens. Potravinarstvo Slovak J. of Food Sci., 10: 272-275.

Sundaresan, N. R.; Anish, D.; Sastry, K. V. H.; Saxena, V. K.; Nagarajan, K.; Subramani, J.; Leo, M. D.; Shit, N.; Mohan, J.; Saxena, M. and Ahmed, K. A. 2008. High doses of dietary zinc induce cytokines, chemokines, and apoptosis in reproductive tissues during regression. Cell and tissue research, 332: 543-554.

Tsai, Y. H.; Mao, S. Y.; Li, M. Z.; Huang, J. T. and Lien, T. F. 2016. Effects of nano size zinc oxide on zinc retention, eggshell quality, immune response and serum parameters of aged laying hens. Anim. feed Sci. and Tech., 213: 99-107.

Vinus and Sheoran N. 2017. Role of Nanotechnology in Poultry Nutrition. Int. J .Pure App. Biosci; 5: 1237-1245.

Yan, F. and Waldroup, P. W. 2006. Evaluation of Mintrex ${ }^{\circledR}$ manganese as a source of manganese for young broilers. Int. J. . Poult. Sci., 5: 708-713.

Young, D. S. and R. B. Friedman 2001. Effects of disease on clinical laboratory tests (Vol. 1). Amer Assn for Clinical Chemistry.

Wang, C.; Zhang, L.; Ying, Z.; He, J.; Zhou, L.; Zhang, L.; Zhong, X. and Wang, T. 2018. Effects of dietary zinc oxide nanoparticles on growth, diarrhea, mineral deposition, intestinal morphology, and barrier of weaned piglets. Biological trace element research, 185: 364-374.

Walsh, C. T.; Sandstead, H. H.; Prasad, A. D. S.; Newberne, P. M. and Fraker, P. J. 1994. Zinc: health effects and research priorities for the 1990s. Environmental health perspectives, 102: 5-46.

Zhao, C. Y.;Tan, S. X.; Xiao, X. Y.; Qiu, X. S.; Pan, J. Q. and Tang, Z. X. 2014. Effects of dietary zinc oxide nanoparticles on growth performance and antioxidative status in broilers. Biological trace element research, 160: 361-367. 
Faten A. M. Attia et al.
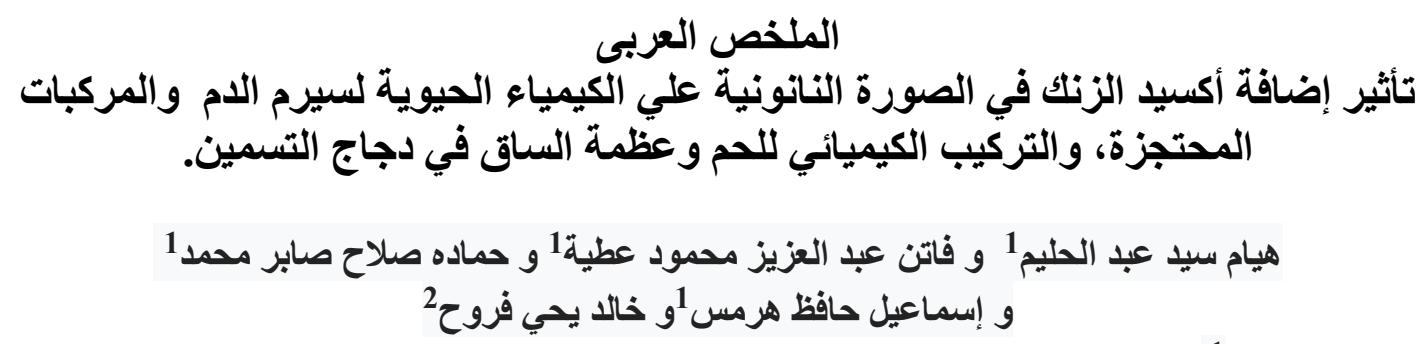

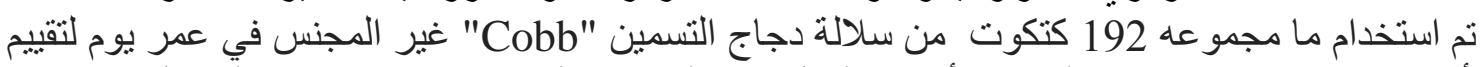
تأثثير إستخدام مستويات مختلفة من أكسيد الزناتك في الصورة النانونية (N-ZnO) على كل من من قدرة

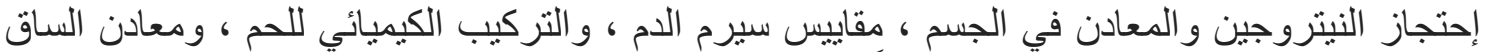

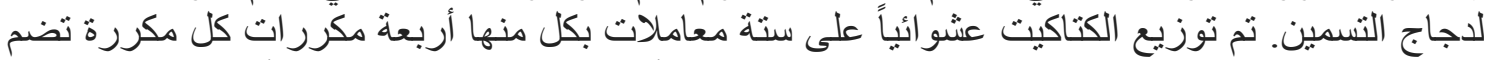

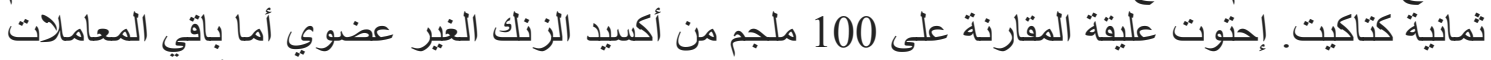

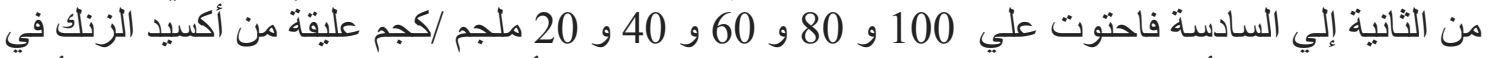
الصورة النانونية. أثرت العلائق المحتوية علي نسب مختلفة من أكسيد الزنلك في صورة النانو تأثنيرا

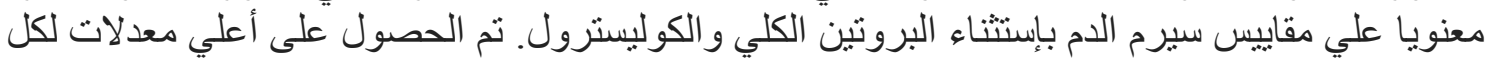

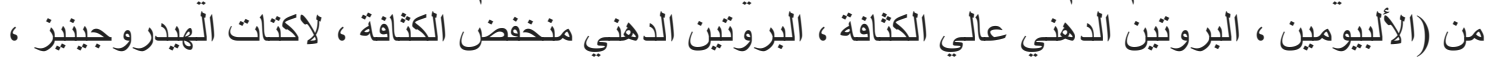

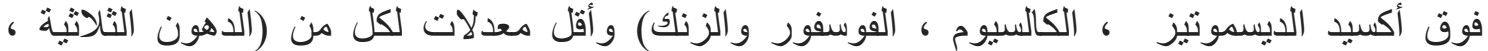

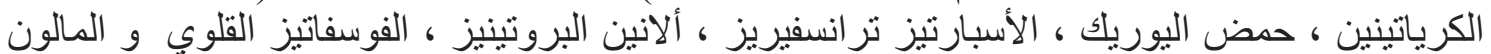

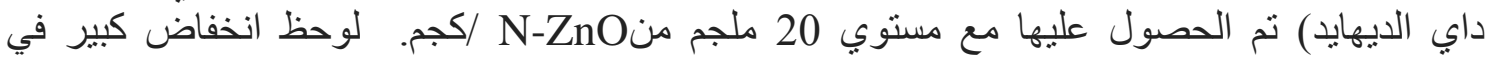

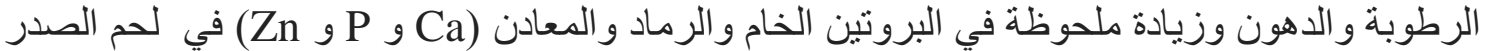
و الفخذ باستخدام المعاملات المحتوية علي N-ZnO ؛ تم تسجيل أدنى و أعلى النسب المئوية ، على المع التو التي ، من المقاييس السابقة مع مستوي20 ملغ

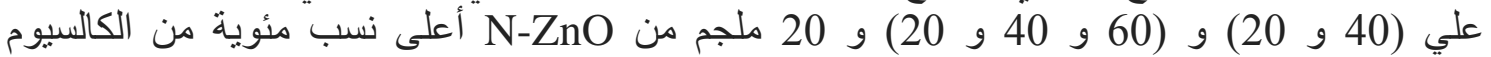
و الفوسفور و الزنلك في الساق على الترتيب. أظهرت الطيور التي غذيت على 40 ملجم من N-ZnO أعلى من

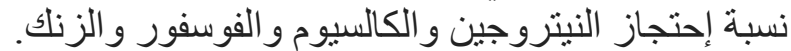

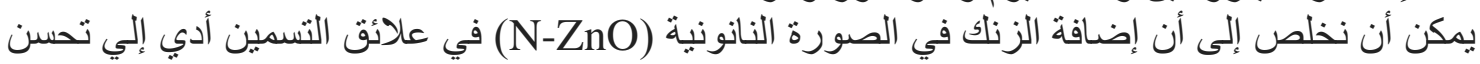

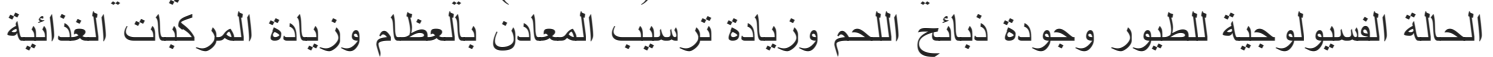
أعطت المستويات المنخفضة من N-ZnO (20 و 40 ملجم/كجم) نتائج واعدة مع عدم وجود تأثنير ضار

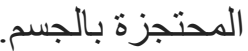
على الحالة الصحية للطيور. 